\title{
Ligand effects on palladium complex catalyzed copolymerization of ethylene/carbon monoxide
}

\author{
K. Rajender Reddy, Wei-Wen Tsai, K. Surekha, Gene-Hsiang Lee, Shie-Ming Peng, \\ Jwu-Ting Chen and Shiuh-Tzung Liu *
}

Department of Chemistry, National Taiwan University, Taipei, Taiwan 106, ROC. E-mail: stliu@ccms.ntu.edu.tw

Received 18th October 2001, Accepted 4th February 2002

First published as an Advance Article on the web 20th March 2002

\begin{abstract}
Several neutral and cationic methyl palladium complexes with bidentate ligands of phosphorus-nitrogen $(\mathrm{P} \sim \mathrm{N})$ donors which form five- or six-membered chelates have been synthesized and characterized. Carbonylation of these complexes generates the corresponding stable $\mathrm{Pd}$-acetyl complexes. The ligands that form a five-membered chelating ring appear to confer better activity towards carbonylation as well as copolymerization of ethylene/CO than do the six-membered analogues. Crystal structures of several inserted intermediates are provided.
\end{abstract}

Late transition metal catalyzed polymerization and/or copolymerization of unsaturated substrates via the migratory insertion route is of great current interest. ${ }^{1,2}$ Many research groups are actively engaged in developing efficient catalysts with late transition metal ions coordinated by various donors. ${ }^{3-9}$ These investigations illustrate that both the electronic and steric environments of the ligand are crucial in stabilizing the metal ion as well as in controlling the selectivity/activity of the polymerization. ${ }^{4,5}$

Unlike homo-donor chelate ligands, hetero-donor systems that have a distinct trans effect might differentiate the migratory insertion path for the incoming substrates. ${ }^{6}$ Thus, the quest for new catalysts with hetero-donor chelate ligands having a combination of hard and soft donors has drawn much attention. ${ }^{6-9}$ Particularly metal complexes with phosphorus and nitrogen donors $(\mathrm{P} \sim \mathrm{N})$ have been found to be useful in organic transformations, ${ }^{10-12}$ as well as polymerization and copolymerization. ${ }^{13}$ In our earlier work, we have demonstrated that palladium complexes with such a donor combination can stabilize various insertion intermediates with $\mathrm{CO}$ and olefins/alkynes, which allows the construction of well-defined copolymers. ${ }^{14}$ In continuation of that work, we examine here the use of palladium complexes bearing various $\mathrm{P} \sim \mathrm{N}$ ligands $\left(\mathrm{L}_{1}-\mathrm{L}_{4}\right)$ (Scheme 1) in insertion processes as well as in ethylene/CO copolymerization.

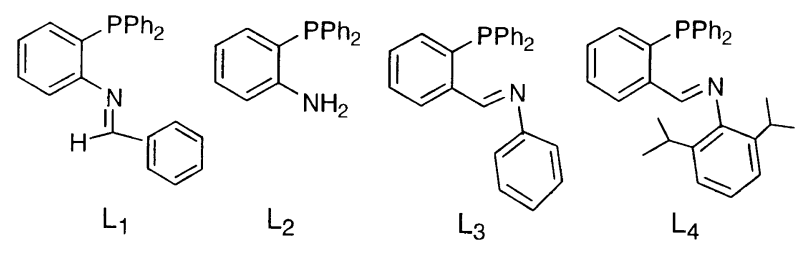

Scheme 1 Various $P \sim N$ ligands studied in this work.

\section{Results and discussion}

\section{Synthesis of ligands and palladium complexes}

Preparations of $\mathrm{L}_{1}$ and its palladium complex [( $\left.\left.\mathrm{L}_{1}\right) \mathrm{PdMeCl}\right] \mathbf{1}$ have been reported in our earlier work, ${ }^{14 b}$ whereas $L_{2}$ was prepared according to the previously published procedure. ${ }^{15 a}$ The ligands $\mathrm{L}_{3}$ and $\mathrm{L}_{4}$ were prepared by simple condensation of 2diphenylphosphinobenzaldehyde with a slight excess of aniline or 2,6-diisopropylaniline respectively in methanol solution. After stirring at room temperature overnight, the corresponding imine product was isolated quantitatively, which was further characterized by spectroscopic methods. ${ }^{31} \mathrm{P}$ NMR shows a single peak at -13.6 and $-14.9 \mathrm{ppm}$ for $\mathrm{L}_{3}$ and $\mathrm{L}_{4}$ respectively, 2-3 ppm upfield from those of the starting 2-diphenylphosphinobenzaldehyde $\left(-11.7 \mathrm{ppm}\right.$ in $\left.\mathrm{CDCl}_{3}\right)$. In the ${ }^{1} \mathrm{H}$ NMR spectra the imine proton appears as a doublet at 9.06 and 8.94 ppm with $J_{\mathrm{P}-\mathrm{H}}=5.1 \mathrm{~Hz}$ for $\mathrm{L}_{3}$ and $J_{\mathrm{P}-\mathrm{H}}=5.7 \mathrm{~Hz}$ for $\mathrm{L}_{4}$. Such long-range coupling is comparable with other known $\mathrm{P} \sim \mathrm{N}$ ligands. ${ }^{16}$

Reactions of equal molar amounts of ligands $\left(\mathrm{L}_{2}-\mathrm{L}_{3}\right)$ with $\mathrm{Pd}(\mathrm{COD}) \mathrm{MeCl}$ [COD = 1,5-cyclooctadiene] in THF solution afforded the complexes $[\mathrm{Pd}(\mathrm{P} \sim \mathrm{N}) \mathrm{MeCl}]\left(\mathrm{P} \sim \mathrm{N}=\mathrm{L}_{2}, \mathbf{2} ; \mathrm{L}_{3}, \mathbf{3}\right)$ in quantitative yields (Eq. 1). A downfield shift of the phosphine

$$
\begin{aligned}
& \mathbf{P} \sim \mathbf{N}+(\mathrm{COD}) \mathrm{PdMeCl} \longrightarrow\left(_{\mathrm{N}^{\prime}}^{P^{2}} \mathrm{Pd}_{\mathrm{Cl}}^{-\mathrm{Me}}\right. \\
& 1 \mathrm{P} \sim \mathrm{N}=\mathrm{L}_{1} \\
& 2 \mathrm{P} \sim \mathrm{N}=\mathrm{L}_{2} \\
& 3 \mathbf{P} \sim \mathrm{N}=\mathrm{L}_{3}
\end{aligned}
$$

signals $(c a .50-60 \mathrm{ppm})$ in ${ }^{31} \mathrm{P}$ NMR with respect to the free ligand reflects the coordination of the phosphine to the palladium metal. The appearance of only one signal in ${ }^{31} \mathrm{P}$ NMR for both complexes $\mathbf{2}$ and $\mathbf{3}$ suggests the formation of a single isomer in each case. The downfield shift of the amine protons in 2 indicates the coordination of nitrogen to the palladium. On the other hand, the imine hydrogen in $\mathbf{3}$ appears at higher field, which is attributed to the conformational change of the ligand upon chelation. The methyl group in $\mathbf{3}$ was established as cis to the phosphine group from the ${ }^{1} \mathrm{H}$ NMR spectrum, where the methyl group bound to the palladium appears as a doublet with a coupling constant $J_{\mathrm{P}-\mathrm{H}} \approx 3.2 \mathrm{~Hz}$. This value is in the typical range reported for the cis-arrangement of the methyl and phosphine groups in $[\mathrm{Pd}(\mathrm{P} \sim \mathrm{N}) \mathrm{MeCl}] .{ }^{17,18}$ In the absence of hydrogen-phosphorus coupling, such an assignment was not available for complex 2 , but confirmation of its structure came from the X-ray structural analysis.

ORTEP diagrams for $\mathbf{2}$ and $\mathbf{3}$ are shown in Figs. 1 and 2 respectively, which show the square planar arrangement around the palladium metal center with the phosphine and methyl groups cis to each other. Selected bond lengths and angles are shown in Table 1, and are in agreement with the reported values 
Table 1 Selected bond distances $(\AA)$ and angles $\left(^{\circ}\right)$ for palladium complexes $^{a}$

\begin{tabular}{llllll}
\hline Compd. & Pd-C(1) & Pd-Cl & Pd-N(1) & Pd-P(1) & Pd-P(2) \\
\hline $\mathbf{1}$ & $2.029(6)$ & $2.375(2)$ & $2.224(4)$ & $2.196(2)$ & \\
$\mathbf{2}$ & $2.039(3)$ & $2.3761(6)$ & $2.172(2)$ & $2.1880(6)$ & \\
$\mathbf{3}$ & $2.040(4)$ & $2.374(1)$ & $2.177(3)$ & $2.196(1)$ & \\
$\mathbf{8}$ & $2.075(7)$ & & $2.183(5)$ & $2.312(2)$ & \\
$\mathbf{9 a}$ & $2.053(2)$ & & $2.165(2)$ & $2.2756(6)$ & $2.333(2)$ \\
$\mathbf{1 1}$ & $1.983(3)$ & $2.3778(7)$ & $2.284(2)$ & $2.2494(7)$ & $2.3214(6)$
\end{tabular}

${ }^{a}$ Crystal structures of $\mathbf{1}$ and $\mathbf{8}$ have been published (see ref. 14b).

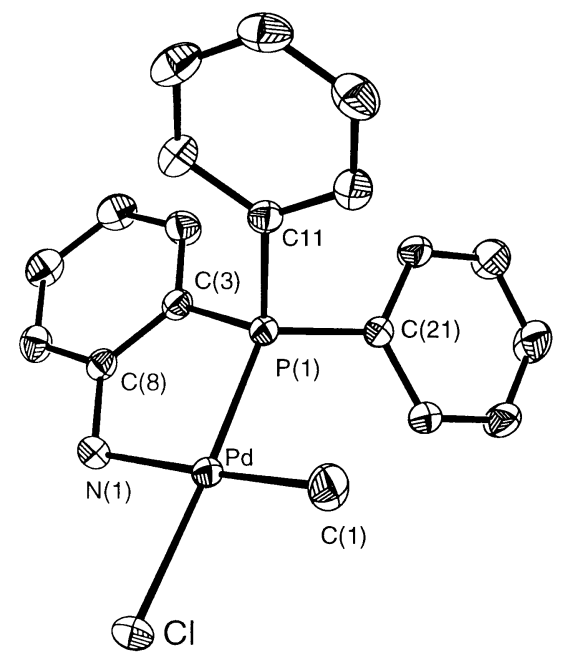

Fig. 1 ORTEP plot of complex 2 with 30\% probability ellipsoids depicted.

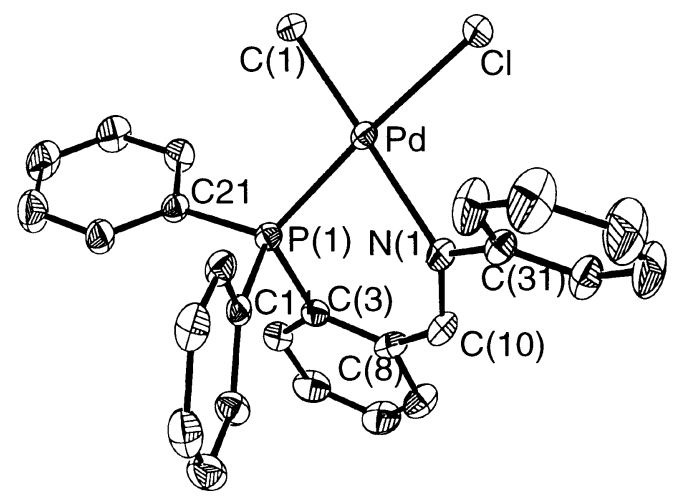

Fig. 2 Molecular structure and atom numbering for complex 3 (30\% probability ellipsoids).

for $[\mathrm{Pd}(\mathrm{P} \sim \mathrm{N}) \mathrm{MeCl}]$ complexes. ${ }^{14 b, 17}$ One exception to be noted is the larger bite angle $(\mathrm{P}-\mathrm{Pd}-\mathrm{N})$ of $85.34(6)^{\circ}$ for 2 compared to the analogous five-membered chelation of complex 1 [81.4 $\left.(1)^{\circ}\right] .^{14 b}$ However, this value is close to that of complex 3 $\left[85.0(1)^{\circ}\right]$, with a six-membered chelating ring. It is generally observed that the bite angle of the five-membered chelate is around $4-5^{\circ}$ less than that of the six-membered analogue. ${ }^{19}$

Cationic complexes 5 and $\mathbf{6}$ with acetonitrile coordination were prepared by treating the related neutral $[\mathrm{PdMeCl}(\mathrm{P} \sim \mathrm{N})]$ with one equiv. of $\mathrm{AgBF}_{4}$ in a mixture of dichloromethane and acetonitrile solution (Eq. 2). Complex 7 was synthesized directly by treating $[\mathrm{Pd}(\mathrm{COD}) \mathrm{MeCl}]$ with one equiv. of $\mathrm{L}_{4}$ and $\mathrm{AgBF}_{4}$ in a solution of dichloromethane and acetonitrile. Such direct synthesis of cationic complexes could also be applied for the preparation of complexes 4-6. The related $\mathrm{PPh}_{3}$ substituted cationic complexes $\left[\mathrm{Pd}\left(\mathrm{L}_{n}\right) \mathrm{Me}\left(\mathrm{PPh}_{3}\right)\right]^{+}(n=2,9 ; n=3,10)$ were prepared by substitution reaction of the corresponding cationic complexes 5 and $\mathbf{6}$ with equimolar amounts of triphenylphos-
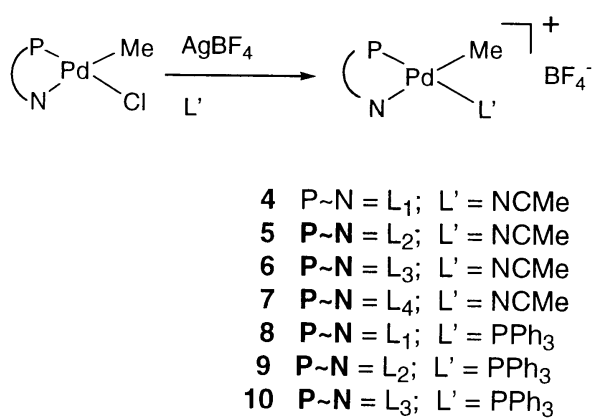

phine. Compounds $\mathbf{4}$ and $\mathbf{8}$ were synthesized and characterized as described in our previous work. ${ }^{14 b}$

Infrared spectra for 4-10 show a broad intense peak around $1100 \mathrm{~cm}^{-1}$ corresponding to the presence of $\mathrm{BF}_{4}^{-}$. The characteristic stretching vibrations of $\mathrm{C} \equiv \mathrm{N}$ for the coordinated acetonitrile were observed with two bands around 2320 and $2290 \mathrm{~cm}^{-1}$. Analogous to the neutral chloride complexes, ${ }^{31} \mathrm{P}$ NMR spectra for 5-7 show only one signal for each complex, indicating the formation of one single stereoisomer out of the two possibilities. The peaks are slightly lower field shifted (1-2 $\mathrm{ppm}$ ) compared to the neutral analogues, presumably due to the more electrophilic nature of the cationic palladium species. A smaller hydrogen-phosphorus coupling $\left(J_{\mathrm{P}-\mathrm{H}} \approx 1.6 \mathrm{~Hz}\right)$ for $\mathrm{Pd}-\mathrm{Me}$ is observed, which is comparable with those of known cis- $[\mathrm{Pd}(\mathrm{P} \sim \mathrm{N}) \mathrm{MeCl}]^{+}$complexes. ${ }^{18}$ On the other hand, ${ }^{31} \mathrm{P} \mathrm{NMR}$ for 9 shows an $\mathrm{AB}+\mathrm{AX}$ spectral pattern, indicating the formation of two isomers in which two phosphines are anti (9a) and syn $(\mathbf{9 b})$ to each other in the ratio of $80: 20$ by integration [To avoid confusion, cis and trans indicate the stereochemical relationship between alkyl and phosphine donors, whereas syn and anti are used for the stereochemical relationship between phosphines throughout this text]. The formation of such isomeric species in 9 is also verified by the ${ }^{1} \mathrm{H}$ NMR spectrum, in which the methyl group bound to palladium appears as a triplet at $0.50 \mathrm{ppm}\left(J_{\mathrm{P}-\mathrm{H}}=6.1 \mathrm{~Hz}\right)$ and a multiplet at $0.83 \mathrm{ppm}$ corresponding to the isomers $9 \mathrm{a}$ and $\mathbf{9 b}$ respectively. However, compound $\mathbf{1 0}$ shows a typical $\mathrm{AB}$ spectrum, which is similar to that of compound 8 reported previously. ${ }^{14 b}$ The formation of similar syn and anti isomers was also reported by Basato and coworkers, who found ${ }^{31} \mathrm{P}$ NMR shifts and coupling values quite comparable to those reported here. ${ }^{20}$

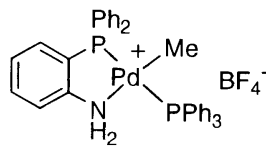

$9 a$

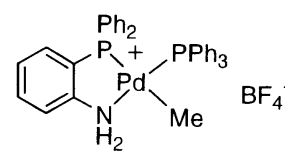

$9 b$
Although ${ }^{1} \mathrm{H}$ and ${ }^{31} \mathrm{P}$ NMR show the formation of two isomeric forms for 9 , re-crystallization from $\mathrm{CH}_{2} \mathrm{Cl}_{2}$ and hexane gave only 9 a as colourless crystals. A crystal structure diagram (Fig. 3) clearly establishes the major isomer where the two phosphines are anti to each other. The $\mathrm{Pd}-\mathrm{C}(1)$ and $\mathrm{Pd}-\mathrm{N}(1)$ bond lengths are within the range reported for 8 . The $\mathrm{Pd}-\mathrm{P}(1)$ bond distance in $9 \mathbf{a}$ is slightly shorter than $\mathrm{Pd}-\mathrm{P}(2)$, which is attributed to the chelating ring of th $\mathrm{P} \sim \mathrm{N}$ ligand. One may note again that the $\mathrm{P}-\mathrm{Pd}-\mathrm{N}$ bite angle for $9 \mathrm{a}\left[83.76(5)^{\circ}\right]$ is larger than that of the analogous five-membered chelate in complex 8 [79.5 (1) $)^{\circ}$.

\section{Insertion of carbon monoxide}

Facile carbonylation of neutral and cationic complexes in $\mathrm{CH}_{2} \mathrm{Cl}_{2}$ solution yielded the corresponding acyl complexes 1115, 17 and 18 within 2-3 h (Eqs. 3 and 4). Selected spectroscopic data for the stable $\mathrm{CO}$ insertion products are given in Table 2. IR absorption for the $\mathrm{C}=\mathrm{O}$ stretching of acyl moiety appears in 
Table 2 Selected $\mathrm{IR}^{a}$ and $\mathrm{NMR}^{b}$ absorptions of $\mathrm{CO}$ insertion products

\begin{tabular}{|c|c|c|c|c|c|}
\hline & $\begin{array}{l}\mathrm{IR} \\
v_{\mathrm{C}-\mathrm{O}}\end{array}$ & $\begin{array}{l}{ }^{1} \mathrm{H} \text { NMR } \\
\text { Pd-COMe }\end{array}$ & Aromatic & $-H \mathrm{C}=\mathrm{N}$ & ${ }^{31} \mathrm{P}$ NMR \\
\hline 11 & 1688 & $2.23(\mathrm{~s})$ & $7.23-8.44$ & $8.55(\mathrm{~m})$ & 14.8 \\
\hline 12 & 1689 & $2.17(\mathrm{~s})$ & $7.24-7.60$ & & 21.0 \\
\hline 13 & 1686 & $2.25(\mathrm{~s})$ & $7.07-7.60$ & $8.12(\mathrm{~s})$ & 20.3 \\
\hline 14 & 1705 & $1.76(\mathrm{~s})$ & $7.18-8.40$ & $9.11(\mathrm{~s})$ & 18.4 \\
\hline 15 & 1696 & $2.07(\mathrm{~s})$ & $7.24-8.18$ & & 22.6 \\
\hline 17 & 1694 & $1.79(\mathrm{~s})$ & $7.14-8.18$ & $8.62(\mathrm{~s})$ & 16.5 and $12.5\left(\mathrm{~d},{ }^{2} J_{\mathrm{PP}}=250\right)$ \\
\hline 18 & 1701 & $1.73(\mathrm{~s})$ & $7.20-7.64$ & & 18.7 and $15.7\left(\mathrm{~d},{ }^{2} J_{\mathrm{PP}}=265\right)$ \\
\hline 19 & 1698 & $1.96(\mathrm{~s})$ & $6.80-8.24$ & $8.40(\mathrm{~s})$ & 19.3 and $15.1\left(\mathrm{~d},{ }^{2} J_{\mathrm{PP}}=264\right)$ \\
\hline
\end{tabular}

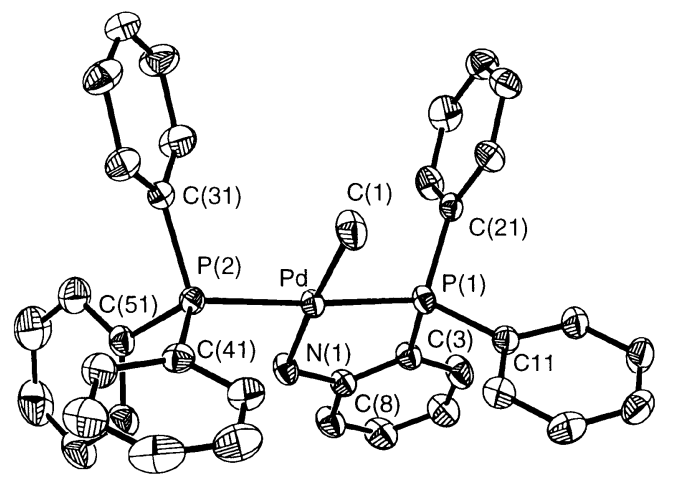

Fig. 3 An ORTEP drawing of $\left[\left(\mathrm{L}_{2}\right) \mathrm{Pd}(\mathrm{Me})\left(\mathrm{PPh}_{3}\right)\right]^{+} \quad \mathbf{9 a} \quad(30 \%$ probability for ellipsoids).

between $1688-1705 \mathrm{~cm}^{-1}$, which are analogous to the reported neutral and cationic metal acyl complexes. ${ }^{14 b, 18}$ Single resonance signal in ${ }^{31} \mathrm{P}$ NMR for 11-15 shows the formation of only one isomer. ${ }^{31} \mathrm{P}$ NMR for $\mathbf{1 8}-\mathbf{1 9}$ shows a typical $\mathrm{AB}$ spectrum, which is expected for two nonequivalent phosphorus nuclei that are anti- to each other. Interestingly, complex $\mathbf{9}$ gave only one carbonylated isomer $\mathbf{1 8 .}$

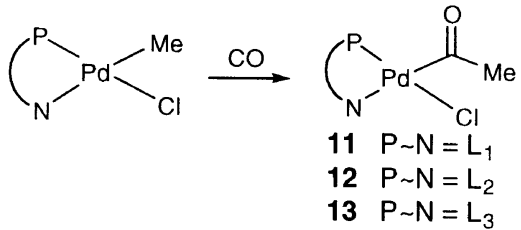

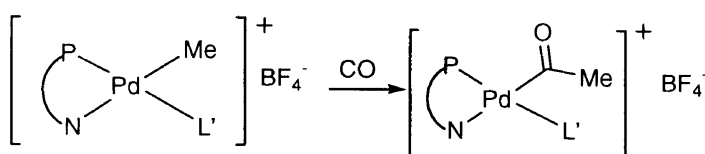

$$
\begin{aligned}
& 14 \mathrm{P} \sim \mathrm{N}=\mathrm{L}_{1} ; \mathrm{L}^{\prime}=\mathrm{NCMe} \\
& 15 \mathrm{P} \sim \mathrm{N}=\mathrm{L}_{2} ; \mathrm{L}^{\prime}=\mathrm{NCMe} \\
& 16 \mathrm{P} \sim \mathrm{N}=\mathrm{L}_{3} ; L^{\prime}=\mathrm{NCMe} \\
& 17 \mathrm{P} \sim \mathrm{N}=\mathrm{L}_{1} ; \mathrm{L}^{\prime}=\mathrm{PPh}_{3} \\
& 18 \quad \mathrm{P} \sim \mathrm{N}=\mathrm{L}_{2 ;} ; \mathrm{L}^{\prime}=\mathrm{PPh}_{3} \\
& 19 \mathrm{P} \sim \mathrm{N}=\mathrm{L}_{3} ; \mathrm{L}^{\prime}=\mathrm{PPh}_{3}
\end{aligned}
$$

Further proof for the $\mathrm{CO}$ insertion came from the X-ray structural analysis of 11; the molecular structure of $\mathbf{1 1}$ is shown in Fig. 4. Selected bond distances and angles are collected in Table 1. The shorter Pd-C(1) bond [1.983 (3) $\AA$ ] in $\mathbf{1 1}$ is due to the $\mathrm{sp}^{2}$ carbon centre of the acetyl group, ${ }^{21,22}$ reflecting the longer $\mathrm{Pd}-\mathrm{N}(1)[2.284(2) \AA]$ bond distance relative to the other complexes reported in this paper.

The stability of the $\mathrm{CO}$ inserted products varied with the nature of both the $\mathrm{P} \sim \mathrm{N}$ bidentate ligand and the cis ancillary ligand. It is generally observed that neutral (11-13) and cationic complexes with $\mathrm{PPh}_{3}$ substitution (17-19) are more stable in solution as well as in the solid state than the acetonitrile

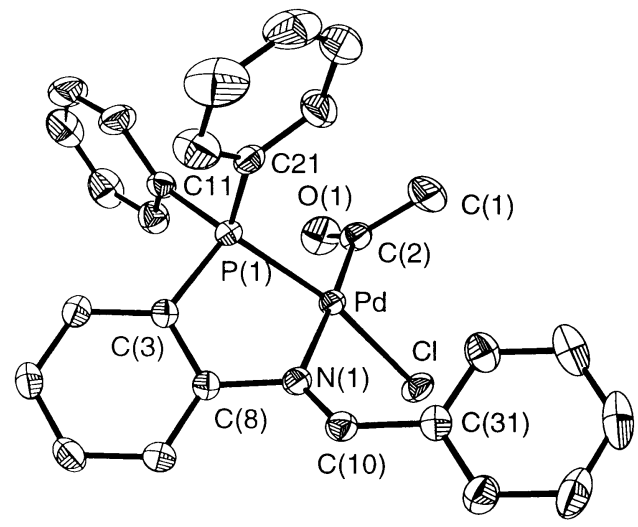

Fig. 4 Molecular structure of complex 11 with 30\% probability ellipsoids depicted.

coordinated cationic complexes $\mathbf{1 4}$ and $\mathbf{1 5}$. A small amount of palladium black formation was observed during the carbonylation reactions, particularly with the weakly coordinated acetonitrile complexes. However, we found that the decomposition of Pd-acyl species could be minimized by carrying out the carbonylation in acetonitrile. Indeed, the pure acyl product $\mathbf{1 5}$ was prepared in acetonitrile. This result shows that the weakly coordinated ligand tends to undergo dissociation, which then leads to the de-insertion of the acyl group.

Carbonylation of complex 6 , the $\mathrm{P} \sim \mathrm{N}$ ligand of which makes a six-membered chelating ring, would not go to completion. Although we observed the $\mathrm{CO}$ insertion product $\left[\left(\mathrm{L}_{3}\right) \mathrm{Pd}(\mathrm{CO}\right.$ $\left.\mathrm{Me})\left(\mathrm{CH}_{3} \mathrm{CN}\right)\right] \mathrm{BF}_{4}(\mathbf{1 6})$ by ${ }^{31} \mathrm{P} \mathrm{NMR}$ under an atmosphere of carbon monoxide, it was always contaminated with the starting material. Longer reaction times led to the precipitation of palladium black. On the other hand such complexes with sixmembered chelation react with strong coordinating ligands such as chloride and $\mathrm{PPh}_{3}$ to yield the carbonylated products $\mathbf{1 3}$ and 19. As for the related five-membered chelating phosphineimine species, it is noticed that compound 14, which could be isolated and stored at low temperature for several days, is much more stable than the acyl complex $16,{ }^{14 a, b}$ suggesting that the six-membered chelate complexes with a weak coordinating ligand are less stable than their five-membered counterparts.

To understand further the activity of the cationic complexes towards carbonylation, a competitive $\mathrm{CO}$ insertion experiment was carried out with complexes 4-7. In NMR tubes charged with 4-7 $(0.01 \mathrm{mmol})$ in $1 \mathrm{ml}$ of $\mathrm{CD}_{3} \mathrm{CN}$ solution individually, carbon monoxide was bubbled through for $30 \mathrm{~min}$. The phosphorus NMR shifts (in $\mathrm{CD}_{3} \mathrm{CN}$ ) as well as the integration of the resulting products with respect to the starting complexes were recorded by ${ }^{31} \mathrm{P}$ NMR spectroscopy. Three ${ }^{31} \mathrm{P}$ NMR signals at 18.35, 22.24 and 20.98 ppm were assigned to $\mathbf{1 4 ,} \mathbf{1 5}$ and 16 based on parallel CO insertion reactions with each complex independently. Integration of the ${ }^{31} \mathrm{P}$ signals shows that the insertion of carbon monoxide into the $\mathrm{Pd}-\mathrm{Me}$ bonds occurs according to the order $\mathbf{4}>\mathbf{5}>\mathbf{6}$. No CO insertion was observed 
Table 3 Results of ethylene/CO copolymerization catalyzed by $\mathbf{4}-\mathbf{1 0}^{a}$

\begin{tabular}{|c|c|c|c|c|c|c|}
\hline Entry & Complex/mmol & Ethylene/CO(psi) & $T /{ }^{\circ} \mathrm{C}$ & $t / \mathrm{h}$ & TON & $\mathrm{g}(\mathrm{PK}) / \mathrm{g}(\mathrm{Pd})$ \\
\hline 1 & $4(0.035)$ & $40 / 40$ & 60 & 48 & 223 & 20.3 \\
\hline 2 & $5(0.04)$ & $40 / 40$ & 60 & 48 & 138 & 14.7 \\
\hline 3 & $6(0.034)$ & $40 / 40$ & 60 & 48 & - & - \\
\hline 4 & $7(0.035)$ & $40 / 40$ & 60 & 48 & - & - \\
\hline 5 & $8(0.025)$ & $40 / 40$ & 60 & 48 & 78 & 5.2 \\
\hline 6 & $9(0.028)$ & $40 / 40$ & 60 & 48 & 51 & 3.7 \\
\hline 7 & $10(0.035)$ & $40 / 40$ & 60 & 48 & - & - \\
\hline $8^{b}$ & $4(0.10)$ & $50 / 50$ & r.t. & 4 & - & Oligomer $^{14 b}$ \\
\hline
\end{tabular}

with complex 7 presumably due to the steric bulk of the substituent on the aryl ring. These results demonstrate that insertion of $\mathrm{CO}$ with the five-membered chelating complexes is faster relative to that of the six-membered analogues.

\section{Copolymerization of ethylene and $\mathrm{CO}$}

Catalytic experiments of the activity of $\mathbf{4 - 1 0}$ for copolymerization of ethylene/CO were carried out in $\mathrm{CH}_{2} \mathrm{Cl}_{2}$ under mild conditions and the results are shown in Table 3. The insoluble white solid was collected and washed with $5 \mathrm{M} \mathrm{HCl}$ followed by water and acetone. Both ${ }^{1} \mathrm{H}$ and ${ }^{13} \mathrm{C}$ NMR spectroscopic data clearly show the formation of polyketone (PK). However, the signal for the end-group is not detected, which is indicative of long-chain polyketone. ${ }^{2 c}$

Among the $[\mathrm{Pd}(\mathrm{P} \sim \mathrm{N}) \mathrm{Me}(\mathrm{NCMe})]^{+}$complexes the catalytic activities of complexes $\mathbf{4}$ and $\mathbf{5}$, in which the $\mathrm{P} \sim \mathrm{N}$ coordination mode adopts a five-membered chelation ring, are much higher (entry 1 and 2), and the activity of the imine is much better than that of the amine. On the other hand, no copolymerization activity was observed with six-membered chelating complexes 6 and 7 (entries 3 and 4). It is not surprising that complex 7 does not show activity for copolymerization, since $\mathrm{CO}$ insertion is not feasible under mild conditions as discussed previously.

In order to understand the activity of the catalysts, two polymerisation intermediates $\mathbf{2 0}$ and $\mathbf{2 1}$ were independently synthesized. Upon subsequent bubbling of $\mathrm{CO}$ and ethylene into a dichloromethane solution of the cationic methylpalladium complex 5 or $\mathbf{6}$, complex 20 or $\mathbf{2 1}$, respectively could be isolated. By monitoring the NMR signal changes of both complexes in chloroform- $\mathrm{d}_{1}$, carbonylation of $\mathbf{2 0}$ appears much faster than that of $\mathbf{2 1}$, illustrating that the polymerization activity of catalyst $\mathbf{4}$ or 5 is much better than that of $\mathbf{6}$ or $\mathbf{7}$. In other words, the palladium(II) complexes with $\mathrm{P} \sim \mathrm{N}$ ligands in five-membered chelating rings are much more reactive toward carbonylation than those in six-membered ones. Since both ligands $\mathrm{L}_{1}$ and $\mathrm{L}_{3}$ have similar donor sites (diphenylphosphino and aromatic imine), the sizes of the donor environment in both $\mathrm{L}_{1}$ and $\mathrm{L}_{3}$ should be alike. Therefore the activity difference between them should result from other factors. As shown in Table 1, the $\mathrm{P}(1)-\mathrm{Pd}-\mathrm{N}(1)$ bite angles in five-membered chelating rings (complexes $\mathbf{1}, \mathbf{8}, \mathbf{1 1}$ ) are smaller than those in sixmembered ones (complexes 2, 3), implying that the bite angle of bidentate ligands has an effect on the catalysis of the copolymerization of ethylene/CO.<smiles>CC1=C[P+](C(F)(F)F)([P+]2([P-])Nc3ccccc3P2)CC1</smiles>

20

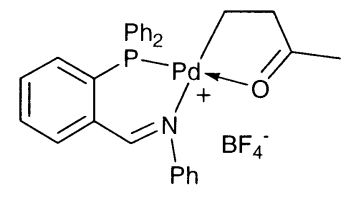

21
Cationic complexes (8 and 9) with $\mathrm{PPh}_{3}$ substitution show a similar trend to that above, but are less active (entries 5 and 6). Although we could not observe any insertion of olefins into these complexes under ambient conditions, the activities of $\mathbf{8}$ and 9 (entries 5 and 6) towards coplymerization suggest that dissociation of the $\mathrm{PPh}_{3}$ ligand is likely to generate a vacant coordination site for the incoming ethylene under elevated temperatures and pressures. Under the mild reaction conditions at room temperature a metal-bound polymer (entry 8) has been isolated and characterized previously, ${ }^{14 b}$ suggesting that the coordination site is necessary for the insertion of unsaturated substrates for polymerization. Again, complex $\mathbf{1 0}$ does not show any catalytic activity for the copolymerization of ethylene/ $\mathrm{CO}$, which is consistent with the behaviour of complex $\mathbf{6}$.

Similar to our present observation, Braunstein and coworkers have reported recently that five-membered chelate complexes with $\mathrm{P} \sim \mathrm{N}$ ligands are better than their six-membered counterparts towards ethylene/CO copolymerization, ${ }^{23}$ indicating that the ring size has an effect on the activity of the catalyst. Indeed this outcome is consistent with the electronic effect through the ligand bite angle in transition-metal complexes proposed by van Leeuwen and coworkers. ${ }^{24}$

In summary, the $\mathrm{P} \sim \mathrm{N}$ bidentate ligands presented in this work allow us to study the influence of the chelation as well as the ancillary ligand on the insertion process with the palladium center. Clearly, the phosphine-imine linked through an $o$ phenylene backbone provides a unique ligand system to stabilize metal-acyl species such as $\mathbf{1 4}$, which is also reflected in the copolymerization of $\mathrm{CO} /$ ethylene. By examining the $\mathrm{N}-\mathrm{Pd}-\mathrm{P}$ angle, the smaller bite angle in $\mathbf{1 4}$ might have an effect on the catalysis of copolymerization.

\section{Experimental}

\section{General information}

All reactions, manipulations and purification steps were performed under a dry nitrogen atmosphere. Tetrahydrofuran was distilled under nitrogen from sodium benzophenone ketyl. Dichloromethane and acetonitrile were dried with $\mathrm{CaH}_{2}$ and distilled under nitrogen. Other chemicals and solvents were of analytical grade and were used as received unless otherwise stated. $\mathrm{Pd}(\mathrm{COD}) \mathrm{MeCl}, \mathrm{L}_{2}$ and $\mathrm{L}_{3}$ were prepared from the earlier reported procedures. ${ }^{14 d, 15} \mathrm{~L}_{1}$ and its corresponding palladium complexes $1,4,8,11,14$ and 16 were prepared from our earlier work. ${ }^{14 b}$

Nuclear magnetic resonance spectra were recorded in $\mathrm{CDCl}_{3}$ on Bruker AC-E 200 or AM-300 spectrometers. Chemical shifts are given in parts per million relative to $\mathrm{Me}_{4} \mathrm{Si}$ for ${ }^{1} \mathrm{H}$ and relative to $85 \% \mathrm{H}_{3} \mathrm{PO}_{4}$ for ${ }^{31} \mathrm{P} \mathrm{NMR}$. Infrared spectra were measured on a Nicolet Magna-IR 550 spectrometer (Series-II) as $\mathrm{KBr}$ pellets, unless otherwise noted.

\section{Synthesis of $L_{3}$ and $L_{4}$}

To a solution of $290 \mathrm{mg}$ (1 mmol) of 2-diphenylphosphinobenzaldehyde in $10 \mathrm{ml}$ of anhydrous methanol under $\mathrm{N}_{2}$ was added $0.2 \mathrm{ml}(2.1 \mathrm{mmol})$ freshly distilled aniline or 2,6diisopropylaniline and the reaction mixture was stirred at room temperature overnight. The pure product $\mathrm{L}_{3}$ was obtained as a 
yellow oil by evaporation of solvent and excess starting material under high vacuum for several hours, whereas ligand $\mathrm{L}_{4}$ was isolated as a pale yellow precipitate, which was filtered and washed with methanol.

$\mathbf{L}_{3} \cdot(90 \%)$. IR (KBr) $1622 \mathrm{~cm}^{-1}\left(v_{\mathrm{C}=\mathrm{N}}\right) ;{ }^{1} \mathrm{H}$ NMR $\left(\mathrm{CDCl}_{3}\right)$ : $\delta 6.65-7.45(\mathrm{~m}, 18 \mathrm{H}), 8.19(\mathrm{~m}, 1 \mathrm{H}), 9.06(\mathrm{~d}, 1 \mathrm{H}, J=5.1 \mathrm{~Hz})$. ${ }^{31} \mathrm{P} \mathrm{NMR}\left(\mathrm{CDCl}_{3}\right): \delta-13.6$. FABMS: $365.1\left(\mathrm{M}^{+}\right)$.

$\mathbf{L}_{4} \cdot(80 \%)$. IR (KBr): $1632 \mathrm{~cm}^{-1}\left(v_{\mathrm{C}=\mathrm{N}}\right) .{ }^{1} \mathrm{H}$ NMR $\left(\mathrm{CDCl}_{3}\right)$ : $\delta 0.99(\mathrm{~d}, J=7.0 \mathrm{~Hz}, 12 \mathrm{H}) 2.74(\mathrm{~m}, 2 \mathrm{H}), 6.94-7.50(\mathrm{~m}, 18 \mathrm{H})$, $8.34(\mathrm{~m}, 1 \mathrm{H}), 8.94(\mathrm{~d}, 1 \mathrm{H}, J=5.7 \mathrm{~Hz}) .{ }^{31} \mathrm{P} \mathrm{NMR}\left(\mathrm{CDCl}_{3}\right)$ : $\delta$-14.9. FABMS: $450.2\left(\mathrm{M}^{+}\right)$.

\section{General procedure for the preparation of 2 and 3}

To a colourless solution of $265 \mathrm{mg}(1 \mathrm{mmol})$ of $\mathrm{Pd}(\mathrm{COD}) \mathrm{MeC}$ in $5 \mathrm{ml} \mathrm{THF}$, an equimolar amount of the ligand in $5 \mathrm{ml} \mathrm{THF}$ solution was added. The mixture was stirred under $\mathrm{N}_{2}$ at room temperature. After $15 \mathrm{~min}$, a white solid began to precipitate; the solution was stirred for another $30 \mathrm{~min}$, the resulting mixture was cooled and the white solid was removed, washed with diethyl ether and dried under vacuum, which resulted in $80-85 \%$ yield of pure product.

Complex 2. ${ }^{1} \mathrm{H}$ NMR: $\delta 0.69$ (s, $\left.3 \mathrm{H}\right), 4.96$ (s, $\left.2 \mathrm{H}\right), 7.22-7.60$ $(\mathrm{m}, 14 \mathrm{H}) .{ }^{31} \mathrm{P}$ NMR $\left(\mathrm{CDCl}_{3}\right)$ : 38.3. Anal. Calcd for $\mathrm{C}_{19} \mathrm{H}_{19^{-}}$ NPCIPd: C, 52.56; H, 4.41; N, 3.22. Found: C, 52.57; H, 4.44; $\mathrm{N}, 3.05 \%$. FABMS: $398.0\left(\mathrm{M}^{+}-\mathrm{Cl}\right)$.

Complex 3. IR ( $\mathrm{KBr}): 1617 \mathrm{~cm}^{-1}\left(v_{\mathrm{C}=\mathrm{N}}\right) .{ }^{1} \mathrm{H}$ NMR $\left(\mathrm{CDCl}_{3}\right)$ : $\delta 0.68(\mathrm{~d}, 3 \mathrm{H}, J=3.2 \mathrm{~Hz}), 7.16-7.60(\mathrm{~m}, 19 \mathrm{H}), 8.18(\mathrm{~d}, 1 \mathrm{H}, J=$ $1.8 \mathrm{~Hz}),{ }^{31} \mathrm{P} \mathrm{NMR}\left(\mathrm{CDCl}_{3}\right)$ : 37.1. Anal. Calcd for $\mathrm{C}_{26} \mathrm{H}_{23}$ NPClPd: C, 59.8; H, 4.43; N, 2.68. Found: C, 59.2; H, 4.25; $\mathrm{N}, 2.83 \%$.

\section{General procedure for the preparation of 5 and 6}

To a solution of the neutral complex 2 or $3(0.5 \mathrm{mmol})$ in $20 \mathrm{ml}$ of $\mathrm{CH}_{2} \mathrm{Cl}_{2}$, an equimolar amount of $\mathrm{AgBF}_{4}$ in $2 \mathrm{ml}$ of $\mathrm{CH}_{3} \mathrm{CN}$ was added under nitrogen and stirred at room temperature for $1 \mathrm{~h}$. The resulting white $\mathrm{AgCl}$ precipitate was filtered through celite and the solvent was removed from the filtrate. The residue was dissolved in a small amount of $\mathrm{CH}_{2} \mathrm{Cl}_{2}$ and upon addition to $\mathrm{Et}_{2} \mathrm{O}$ a precipitate was deposited, which was filtered and dried under vacuum, resulted in $85-90 \%$ yield of pure product.

Complex 5. ${ }^{1} \mathrm{H}$ NMR $\left(\mathrm{CDCl}_{3}\right): \delta 0.53(\mathrm{~d}, 3 \mathrm{H}, J=1.6 \mathrm{~Hz})$, $2.35(\mathrm{~s}, 3 \mathrm{H}), 5.21(\mathrm{~s}, 2 \mathrm{H}), 7.23-7.71(\mathrm{~m}, 14 \mathrm{H}) .{ }^{31} \mathrm{P}$ NMR $\left(\mathrm{CDCl}_{3}\right)$ : 40.6. Anal. Calcd for $\mathrm{C}_{21} \mathrm{H}_{22} \mathrm{~N}_{2} \mathrm{PBF}_{4} \mathrm{Pd}: \mathrm{C}, 47.89$; $\mathrm{H}, 4.21$; N, 5.32. Found: C, 48.08; H, 4.21; N, 5.13\%. FABMS: $m / z=398.0\left(\mathrm{M}^{+}-\mathrm{NCMe}\right)$.

Complex 6. IR ( $\mathrm{KBr}): 1618 \mathrm{~cm}^{-1}\left(v_{\mathrm{C}=\mathrm{N}}\right) .{ }^{1} \mathrm{H}$ NMR $\left(\mathrm{CDCl}_{3}\right)$ : $\delta 0.44(\mathrm{~d}, 3 \mathrm{H}, J=1.7 \mathrm{~Hz}), 1.89(\mathrm{~s}, 3 \mathrm{H}), 7.10-7.90(\mathrm{~m}, 19 \mathrm{H})$ $8.38(\mathrm{~s}, 1 \mathrm{H}) .{ }^{31} \mathrm{P} \mathrm{NMR}\left(\mathrm{CDCl}_{3}\right)$ : 38.8. Anal. Calcd for $\mathrm{C}_{28} \mathrm{H}_{26} \mathrm{~N}_{2} \mathrm{PBF}_{4} \mathrm{Pd}$ : C, 54.71; H, 4.26; N, 4.56. Found: C, 53.72; $\mathrm{H}, 4.42, \mathrm{~N}, 4.38 \%$. FABMS: $m / z=486.1\left(\mathrm{M}^{+}-\mathrm{NCMe}\right)$.

\section{Preparation of complex 7}

To a mixture of $[\mathrm{Pd}(\mathrm{COD}) \mathrm{MeCl}](265 \mathrm{mg}, 1 \mathrm{mmol})$ and $\mathrm{L}_{4}$ (1.1 mmol) in $20 \mathrm{ml}$ of $\mathrm{CH}_{2} \mathrm{Cl}_{2}$, a stoichiometric amount of $\mathrm{AgBF}_{4}(1 \mathrm{mmol})$ in $2 \mathrm{ml}$ of $\mathrm{CH}_{3} \mathrm{CN}$ was added under nitrogen and stirred at room temperature for $1 \mathrm{~h}$. The workup procedure is similar to that for $5(87 \%)$ : IR $(\mathrm{KBr}): 1629 \mathrm{~cm}^{-1}\left(v_{\mathrm{C}=\mathrm{N}}\right)$; ${ }^{1} \mathrm{H}$ NMR $\left(\mathrm{CDCl}_{3}\right): \delta 0.53(\mathrm{~d}, 3 \mathrm{H}, J=1.32 \mathrm{~Hz}), 0.83(\mathrm{~d}, 6 \mathrm{H}, J=$ $6.85 \mathrm{~Hz}), 1.20(\mathrm{~d}, 6 \mathrm{H}, J=6.77 \mathrm{~Hz}), 1.81(\mathrm{~s}, 3 \mathrm{H}), 2.82(\mathrm{~m}, 2 \mathrm{H})$, 7.11-7.85 (m, $17 \mathrm{H}), 8.21(\mathrm{~s}, 1 \mathrm{H}) .{ }^{31} \mathrm{P}$ NMR $\left(\mathrm{CDCl}_{3}\right): 37.7$. Anal. Calcd for $\mathrm{C}_{34} \mathrm{H}_{38} \mathrm{~N}_{2} \mathrm{PBF}_{4} \mathrm{Pd}$ : C, 58.43; H, 4.48; N, 4.01. Found: C, 58.35; H, 4.62; N, 3.96\%. FABMS: $m / z=570.1$ $\left(\mathrm{M}^{+}-\mathrm{NCMe}\right)$.

\section{General procedure for the preparation of 9 and 10}

To a solution of the cationic complex 5 or $\mathbf{6}(0.5 \mathrm{mmol})$ in $20 \mathrm{ml}$ of THF, an equimolar amount of $\mathrm{PPh}_{3}$ was added under nitrogen and the reaction mixture was stirred for $1 \mathrm{~h}$. After removal of solvents, the residue was washed with $\mathrm{Et}_{2} \mathrm{O}$ and dried under vacuum to yield the desired complex as a white solid (85-90\%).

Complex 9. 9a: ${ }^{1} \mathrm{H}$ NMR $\left(\mathrm{CDCl}_{3}\right): \delta 0.50(\mathrm{t}, 3 \mathrm{H}, J=6.1 \mathrm{H})$, $4.82(\mathrm{~s}, 2 \mathrm{H}), 6.96-7.61(\mathrm{~m}, 29 \mathrm{H}) .{ }^{31} \mathrm{P}$ NMR $\left(\mathrm{CDCl}_{3}\right): 33.2$ and $26.5\left(\mathrm{~d},{ }^{2} J_{\mathrm{PP}}=392 \mathrm{~Hz}\right) .9 \mathrm{~b}: 0.83(\mathrm{~m}, 3 \mathrm{H}), 5.89(\mathrm{~s}, 2 \mathrm{H}) ;{ }^{31} \mathrm{P}$ NMR $\left(\mathrm{CDCl}_{3}\right): \delta 39.6$ and $26.0\left(\mathrm{~d},{ }^{2} J_{\mathrm{PP}}=27 \mathrm{~Hz}\right)$. Anal. Calcd for $\mathrm{C}_{37} \mathrm{H}_{34} \mathrm{NP}_{2} \mathrm{BF}_{4} \mathrm{Pd}$ : C, 59.43; H, 4.58; N, 1.87. Found: C, 58.96; $\mathrm{H}, 4.64 ; \mathrm{N}, 1.80 \%$. FABMS: $m / z=660.2\left(\mathrm{M}^{+}\right)$.

Complex 10. IR ( $\mathrm{KBr}): 1620 \mathrm{~cm}^{-1}\left(v_{\mathrm{C}=\mathrm{N}}\right) .{ }^{1} \mathrm{H}$ NMR $\left(\mathrm{CDCl}_{3}\right)$ : $\delta 0.45(\mathrm{t}, 3 \mathrm{H}, J=6.0 \mathrm{~Hz}), 6.88-7.86(\mathrm{~m}, 33 \mathrm{H}), 8.24(\mathrm{~m}, 1 \mathrm{H})$, $8.40(\mathrm{~s}, 1 \mathrm{H}) \cdot{ }^{31} \mathrm{P}$ NMR $\left(\mathrm{CDCl}_{3}\right): \delta 32.9$ and $25.1\left(\mathrm{~d},{ }^{2} J_{\mathrm{PP}}=\right.$ $398 \mathrm{~Hz}$ ). Anal. Calcd for $\mathrm{C}_{44} \mathrm{H}_{38} \mathrm{NP}_{2} \mathrm{BF}_{4} \mathrm{Pd}$ : C, 63.20; H, 4.58; $\mathrm{N}, 2.67$. Found: $\mathrm{C}, 62.82 ; \mathrm{H}, 4.78 ; \mathrm{N}, 1.56 \%$. FABMS: $m / z=$ $748.2\left(\mathrm{M}^{+}\right)$.

General procedure for the preparation of $12,13,15,17,18$ and 19

From a solution of the relevant neutral or cationic complex $(0.25 \mathrm{mmol})$ in $10 \mathrm{ml}$ of $\mathrm{CH}_{2} \mathrm{Cl}_{2}$, continuous bubbling of carbon monoxide for $2-4 \mathrm{~h}$ resulted in pure $\mathrm{CO}$ inserted products. The resulting solutions were cooled and filtered through celite (a small amount of Pd black formation was observed in all these reactions), the filtrate was evaporated to a small volume and precipitated by the addition of ether. The desired complex was precipitated as a light yellow solid, which was collected and dried under vacuum. Yields range from $75 \%$ to $80 \%$.

Complex 12. IR (KBr): $1689 \mathrm{~cm}^{-1}\left(v_{\mathrm{C}=\mathrm{O}}\right) .{ }^{1} \mathrm{H}$ NMR $\left(\mathrm{CDCl}_{3}\right)$ : $\delta 2.17$ (s, $3 \mathrm{H}), 4.59$ (s, $2 \mathrm{H}), 7.24-7.60(\mathrm{~m}, 16 \mathrm{H}) .{ }^{31} \mathrm{P} \mathrm{NMR}$ $\left(\mathrm{CDCl}_{3}\right)$ : 21.0. Anal. Calcd for $\mathrm{C}_{20} \mathrm{H}_{19} \mathrm{NPOClPd}$ C, 51.97; $\mathrm{H}, 4.14$; N, 3.03. Found: C, 51.88; H, 4.02; N, 2.88\%. FABMS: $\mathrm{m} / \mathrm{z}=426.0\left(\mathrm{M}^{+}-\mathrm{Cl}\right)$.

Complex 13. IR (KBr): $1686 \mathrm{~cm}^{-1}\left(v_{\mathrm{C}=\mathrm{O}}\right) .{ }^{1} \mathrm{H}$ NMR $\left(\mathrm{CDCl}_{3}\right)$ : $\delta 2.25$ (s, $3 \mathrm{H}), 7.07-7.60(\mathrm{~m}, 19 \mathrm{H}), 81.2$ (s, $1 \mathrm{H}) .{ }^{31} \mathrm{P}$ NMR 20.3. Anal. Calcd for $\mathrm{C}_{27} \mathrm{H}_{23} \mathrm{NOPClPd}$ : C, 58.92; H, 4.21; N, 2.54 . Found: C, 58.52; H, 4.25; N, 2.51\%.

Complex 15. IR ( $\mathrm{KBr}): 1696 \mathrm{~cm}^{-1}\left(v_{\mathrm{C}-0}\right) ;{ }^{1} \mathrm{H}$ NMR $\left(\mathrm{CDCl}_{3}\right)$ : $\delta 2.07(\mathrm{~s}, 3 \mathrm{H}), 2.34(\mathrm{~s}, 3 \mathrm{H}), 4.87(\mathrm{~s}, 2 \mathrm{H}), 7.24-7.60(\mathrm{~m}, 16 \mathrm{H})$. ${ }^{31} \mathrm{P}$ NMR $\left(\mathrm{CDCl}_{3}\right):$ 22.6. Anal. Calcd for $\mathrm{C}_{22} \mathrm{H}_{22} \mathrm{~N}_{2} \mathrm{POBF}_{4} \mathrm{Pd}$ : C, 47.64; H, 3.99; N, 5.05. Found: C, 47.35; H, 3.89; N, 4.56\%. FABMS: $m / z=426.0\left(\mathrm{M}^{+}-\mathrm{NCMe}\right)$.

Complex 17. IR ( $\mathrm{KBr}): 1694 \mathrm{~cm}^{-1}\left(v_{\mathrm{C}-\mathrm{O}}\right) .{ }^{1} \mathrm{H}$ NMR $\left(\mathrm{CDCl}_{3}\right)$ : $\delta 8.62(\mathrm{~s}, 1 \mathrm{H}), 8.18(\mathrm{~d}, 2 \mathrm{H}, J=6.7 \mathrm{~Hz}), 7.83-7.14(\mathrm{~m}, 32 \mathrm{H})$, $1.79(\mathrm{~s}, 3 \mathrm{H}) .{ }^{31} \mathrm{P}$ NMR: $\delta 16.5$ and $12.5\left(\mathrm{~d},{ }^{2} J_{\mathrm{PP}}=250 \mathrm{~Hz}\right)$. Anal. Calcd for $\mathrm{C}_{45} \mathrm{H}_{38} \mathrm{BF}_{4} \mathrm{NOP}_{2} \mathrm{Pd}: \mathrm{C}, 62.56 ; \mathrm{H}, 4.43 ; \mathrm{N}, 1.62$. Found: C, $62.21 ; \mathrm{H}, 4.24 ; \mathrm{N}, 1.35 \%$.

Complex 18. IR (KBr): $1701 \mathrm{~cm}^{-1}\left(v_{\mathrm{C}=0}\right) .{ }^{1} \mathrm{H}$ NMR $\left(\mathrm{CD}_{3} \mathrm{CN}\right)$ : $\delta 2.23(\mathrm{~s}, 3 \mathrm{H}), 4.65\left(\mathrm{~s}, 2 \mathrm{H}, \mathrm{NH}_{2}\right), 7.20-7.64(\mathrm{~m}, 16 \mathrm{H})$. ${ }^{31} \mathrm{P}$ NMR $\left(\mathrm{CD}_{3} \mathrm{CN}\right)$ : 18.7 and $15.7\left(\mathrm{~d},{ }^{2} J_{\mathrm{PP}}=265 \mathrm{~Hz}\right)$. Anal. Calcd for $\mathrm{C}_{38} \mathrm{H}_{34} \mathrm{NP}_{2} \mathrm{OBF}_{4} \mathrm{Pd}$ : C, 58.82; H, 4.42; N, 1.81 . Found: C, 58.11; H, 4.54; N, 1.64\%. FABMS: $m / z=688.3\left(\mathrm{M}^{+}\right)$.

Complex 19. IR (KBr): $1698\left(v_{\mathrm{C}=\mathrm{O}}\right), 1618 \mathrm{~cm}^{-1}\left(v_{\mathrm{C}=\mathrm{N}}\right) ;{ }^{1} \mathrm{H}$ NMR $\left(\mathrm{CDCl}_{3}\right) \delta 1.96(\mathrm{~s}, 3 \mathrm{H}), 6.80-7.87(\mathrm{~m}, 33 \mathrm{H}), 8.24(\mathrm{~m}, 1 \mathrm{H}), 8.40$ (s, 1H) ${ }^{31}$ P NMR: 9.3 and $15.1\left(\mathrm{~d},{ }^{2} J_{\mathrm{PP}}=264 \mathrm{~Hz}\right)$.

\section{Other complexes}

Complex 20. A solution of complex $5(60.0 \mathrm{mg})$ in $10 \mathrm{ml}$ of $\mathrm{CH}_{3} \mathrm{CN}$ was reacted with $\mathrm{CO}(100 \mathrm{psi})$ in an autoclave for 
Table 4 Summary of crystallographic data for complexes 2, 3, 9a and 11

\begin{tabular}{|c|c|c|c|c|}
\hline Complex & 2 & 3 & $9 \mathbf{a}$ & 11 \\
\hline Formula & $\mathrm{C}_{19} \mathrm{H}_{19} \mathrm{ClNPPd}$ & $\mathrm{C}_{26} \mathrm{H}_{27} \mathrm{ClNO}_{2} \mathrm{PPd}$ & $\mathrm{C}_{37} \mathrm{H}_{34} \mathrm{BF}_{4} \mathrm{NP}_{2} \mathrm{Pd}$ & $\mathrm{C}_{28} \mathrm{H}_{25} \mathrm{Cl}_{3} \mathrm{NOPPd}$ \\
\hline Fw & 434.17 & 558.31 & 747.80 & 635.21 \\
\hline Crystal system & Triclinic & Triclinic & Monoclinic & Triclinic \\
\hline$a / \AA$ & $9.6838(3)$ & $8.9142(2)$ & $16.6481(2)$ & $9.5745(1)$ \\
\hline$b / \AA$ & $9.8823(3)$ & $10.3657(2)$ & $10.6638(1)$ & $9.8728(1)$ \\
\hline$c / \AA$ & $10.5044(3)$ & $14.4963(3)$ & $19.8024(2)$ & $15.3826(2)$ \\
\hline$\alpha /^{\circ}$ & $81.180(1)$ & $103.052(1)$ & 90 & $79.672(1)$ \\
\hline$\beta /^{\circ}$ & $89.079(1)$ & $101.345(1)$ & $101.990(1)$ & $83.546(1)$ \\
\hline$\gamma /{ }^{\circ}$ & $65.848(1)$ & $92.264(1)$ & 90 & $81.263(1)$ \\
\hline$V / \AA^{3}$ & $905.20(5)$ & $1274.43(5)$ & $3438.86(6)$ & $1408.48(3)$ \\
\hline$T / \mathrm{K}$ & $295(2)$ & $295(2)$ & $295(2)$ & $295(2)$ \\
\hline$Z$ & 2 & 2 & 4 & 2 \\
\hline$\mu / \mathrm{mm}^{-1}$ & 1.259 & 0.918 & 0.681 & 1.021 \\
\hline Space group & $P \overline{1}$ & $P \overline{1}$ & $P 2_{1} / n$ & $P \overline{1}$ \\
\hline Reflns collected & 9868 & 16566 & 23327 & 18402 \\
\hline Independent reflns & $4121\left(R_{\mathrm{int}}=0.0270\right)$ & $5854\left(R_{\mathrm{int}}=0.0472\right)$ & $7866\left(R_{\mathrm{int}}=0.0262\right)$ & $6472\left(R_{\mathrm{int}}=0.0335\right)$ \\
\hline$R_{1}[I>2 \sigma(I)]$ & 0.0262 & 0.0526 & 0.0333 & 0.0370 \\
\hline$w R_{2}[I>\sigma(I)]$ & 0.0579 & 0.1215 & 0.0781 & 0.0782 \\
\hline
\end{tabular}

4 hours. The resulting solution was filtered through celite and evaporated to dryness. After verifying the completion of $\mathrm{CO}$ insertion by NMR spectroscopy, the solid was dissolved in $10 \mathrm{ml}$ of $\mathrm{CH}_{2} \mathrm{Cl}_{2}$, and ethylene was bubbled through for $2 \mathrm{~h}$. The resulting solution was again filtered through celite and dried under vacuum. The solid was dissolved in a small amount of $\mathrm{CH}_{2} \mathrm{Cl}_{2}$ and added to large amount of diethyl ether, which generated the pure product $(49.2 \mathrm{mg}, 77 \%)$. IR $(\mathrm{KBr}): 1642$ $\mathrm{cm}^{-1}\left(v_{\mathrm{C}=\mathrm{O}}\right) ;{ }^{1} \mathrm{H}$ NMR $\left(\mathrm{CDCl}_{3}\right): \delta 1.74(\mathrm{t}, J=6.6 \mathrm{~Hz}, 2 \mathrm{H}$, $\left.\mathrm{PdCH}_{2} \mathrm{CH}_{2}\right), 2.30\left(\mathrm{~s}, 3 \mathrm{H}, \mathrm{COCH}_{3}\right), 3.05(\mathrm{t}, J=6.6 \mathrm{~Hz}, 2 \mathrm{H}$, $\mathrm{CH}_{2} \mathrm{CH}_{2} \mathrm{CO}$ ), 5.46 (s, $2 \mathrm{H}, \mathrm{Pd}-\mathrm{NH}_{2}$ ), 7.25-7.35 (m, $\left.2 \mathrm{H}\right), 7.45$ $7.56(\mathrm{~m}, 11 \mathrm{H}), 7.73(\mathrm{~m}, 1 \mathrm{H}) .{ }^{13} \mathrm{C} \mathrm{NMR}\left(\mathrm{CDCl}_{3}\right): \delta 20.4,27.8$, $50.3\left(\mathrm{COCH}_{3}\right), 233.9\left(\mathrm{COCH}_{3}\right) .{ }^{31} \mathrm{P}$ NMR $\left(\mathrm{CDCl}_{3}\right): \delta 38.1$. Anal. Calcd for $\mathrm{C}_{22} \mathrm{H}_{23} \mathrm{NBF}_{4} \mathrm{OPPd}$ : C, $48.79 ; \mathrm{H}, 4.28 ; \mathrm{N}, 2.59$. Found: C, 48.47; H, 4.45; N, 2.64\%.

Complex 21. This complex was prepared by a similar procedure as described for 20 starting with complex $\mathbf{6}$ (50 mg): IR $(\mathrm{KBr}): 1636 \mathrm{~cm}^{-1}\left(v_{\mathrm{C}-\mathrm{O}}\right) ;{ }^{1} \mathrm{H}$ NMR $\left(\mathrm{CDCl}_{3}\right): \delta 1.50(\mathrm{t}, J=7 \mathrm{~Hz}$, $\left.2 \mathrm{H}, \mathrm{PdCH}_{2} \mathrm{CH}_{2}\right), 2.17$ (s, 3H, COCH$H_{3}, 3.07$ (t, $J=7 \mathrm{~Hz}, 2 \mathrm{H}$ $\left.\mathrm{CH}_{2} \mathrm{CH}_{2} \mathrm{CO}\right), 7.17-7.27(\mathrm{~m}, 5 \mathrm{H}), 7.31-7.58(\mathrm{~m}, 12 \mathrm{H}), 7.60(\mathrm{~m}$, $1 \mathrm{H}), 7.76(\mathrm{~m}, 1 \mathrm{H}) ;{ }^{13} \mathrm{C}$ NMR $\left(\mathrm{CDCl}_{3}\right): \delta 24.7,27.7,51.0$ $\left(\mathrm{COCH}_{3}\right), \quad 165.5(\mathrm{Pd}-\mathrm{N}=\mathrm{C}), 233.8 \quad\left(\mathrm{COCH}_{3}\right) ;{ }^{31} \mathrm{P}$ NMR $\left(\mathrm{CDCl}_{3}\right): \delta$ 36.9. Anal. Calcd for $\mathrm{C}_{29} \mathrm{H}_{27} \mathrm{NBF}_{4} \mathrm{OPPd}$ : C, 55.31; $\mathrm{H}, 4.32 ; \mathrm{N}, 2.22$. Found: C, 55.11; H, 4.64; N, 2.54\%.

\section{Copolymerization of ethylene/CO}

The catalysts were introduced into a stainless-steel autoclave (500 $\mathrm{ml}$ ) by dissolution in $\mathrm{CH}_{2} \mathrm{Cl}_{2}(70 \mathrm{ml})$. The reaction mixture was then pressurized with a mixture of $\mathrm{CO}$ (40 psi) and ethylene (40 psi) and stirred at constant temperature. Reaction was stopped after the specified time and the resulting white solid was collected and washed with $5 \mathrm{M} \mathrm{HCl}$ followed by water and acetone. Results are summarized in Table 3. IR (KBr) 1691 $\mathrm{cm}^{-1}\left(v_{\mathrm{C}=\mathrm{O}}\right) .{ }^{1} \mathrm{H} \mathrm{NMR}\left(\mathrm{CDCl}_{3}+\mathrm{CF}_{3} \mathrm{COOH}\right): \delta 2.84(\mathrm{~s}),{ }^{13} \mathrm{C}$ $\mathrm{NMR}\left(\mathrm{CDCl}_{3}+\mathrm{CF}_{3} \mathrm{COOH}\right): \delta 36.2,213.8$.

\section{Crystallography}

Crystals suitable for X-ray determination were obtained for $\mathbf{2}$ 3, 9a and $\mathbf{1 1}$ by slow diffusion of hexane into a dichloromethane solution at room temperature. Cell parameters were determined by using a Bruker SMART CCD diffractometer. Selected bond distances and bond angles are collected in Table 1. A summary of the crystallographic data is deposited in Table 4.

CCDC reference numbers 172819-172822.

See http://www.rsc.org/suppdata/dt/b1/b109290a/ for crystallographic data in CIF or other electronic format.

\section{Acknowledgements}

We thank the National Science Council for financial support (NSC89-2113-M-002-070).

\section{References}

1 (a) S. D. Ittel, L. K. Johnson and M. Brookhart, Chem. Rev., 2000, 100, 1169; (b) E. Drent and P. H. M. Budzelaar, Chem. Rev., 1996, 96, 663 .

2 (a) G. J. P. Britovsek, V. C. Gibson and D. F. Wass, Angew. Chem., Int. Ed., 1999, 38, 428; (b) K. J. Cavell, Coord. Chem. Rev., 1996, 155, 209; (c) A. Sen, Acc. Chem. Res., 1993, 26, 303.

3 (a) T. R. Younkin, E. F. Connor, J. I. Henderson, S. K. Friedrich, R. H. Grubbs and D. A. Bansleben, Science, 2000, 287, 460; (b) G. J. P. Britovsek, M. Bruce, V. C. Gibson, B. S. Kimberley, P. J. Maddox, S. Mastroianni, S. J. McTavish, C. Redshaw, G. A. Solan, S. Stromberg, A. J. P. White and D. J. Williams, J. Am. Chem. Soc., 1999, 121, 8728; (c) W. Keim, New J. Chem., 1994, 18, 93; (d) C. Wang, S. Friedrich, T. R. Younkin, R. T. Li, R. H. Grubbs, D. A. Bansleben and M. W. Day, Organometallics, 1998, 17, 3149.

4 E. Drent, J. A. M. van Breokhoven and M. J. Doyle, J. Organomet. Chem., 1991, 417, 235.

5 (a) L. K. Johnson, C. M. Killian and M. Brookhart, J. Am. Chem. Soc., 1995, 117, 6414; (b) C. M. Killian, D. J. Tempel, L. K. Johnson and M. Brookhart, J. Am. Chem. Soc., 1996, 118, 11664.

6 G. P. C. M. Dekker, A. Buijs, C. J. Elsevier, K. Vrieze, P. W. N. M. van Leeuwen, W. J. J. Smeets, A. L. Spek, Y. F. Wang and C. H. Stam, Organometallics, 1992, 11, 1937.

7 (a) A. Bader and E. Lindner, Coord. Chem. Rev., 1991, 108, 27; (b) E. Lindner, S. Pautz and M. Haustein, Coord. Chem. Rev., 1996, 155, 145; (c) G. J. P. Britovsek, W. Keim, S. Mecking, D. Sainz and T. Wagner, J. Chem. Soc., Chem. Commun., 1993, 1632; (d) K. S. Coleman, M. L. H. Green, S. I. Pascu, N. H. Rees, A. R. Cowley and L. H. Rees, J. Chem. Soc., Dalton Trans., 2001, 3384.

8 P. Espinet and K. Soulantica, Coord. Chem. Rev., 1999, 193-195, 499

9 (a) E. Hauptman, P. J. Fagan and W. Marshall, Organometallics, 1999, 18, 2061; (b) A. Albinati, J. Eckert, P. Pregosin, H. Ruegger, R. Salzmann and C. Stossel, Organometallics, 1997, 16, 579.

10 (a) O. Loiseleur, M. Hayashi, M. Keenan, N. Schmees and A. Pfaltz, J. Organomet. Chem., 1999, 576, 16; (b) E. Shirakawa, H. Yoshida, T. Kurahashi, Y. Nakao and T. Hiyama, J. Am. Chem. Soc., 1998, 120, 2975.

11 G. Helmchen and A. Pfaltz, Acc. Chem. Res., 2000, 33, 336 and references therein.

12 K. R. Reddy, K. Surekha, G.-H. Lee, S.-M. Peng, J.-T. Chen and S.-T. Liu, Organometallics, 2000, 19, 2637.

13 (a) E. K. van den Beuken, W. J. J. Smeets, A. L. Spek and B. L. Feringa, Chem. Commun., 1998, 223; (b) A. Aeby, A. Gsponer and G. Consiglio, J. Am. Chem. Soc., 1998, 120, 11000; (c) A. Aeby, F. Bangerter and G. Consiglio, Helv. Chim. Acta, 1998, 81, 764 and references therein.

14 (a) K. R. Reddy, C.-L. Chen, Y.-H. Liu, S.-M. Peng, J.-T. Chen and S.-T. Liu, Organometallics, 1999, 18, 2574; (b) K. R. Reddy, K. Surekha, G.-H. Lee, S.-M. Peng, J.-T. Chen and S.-T. Liu, 
Organometallics, 2001, 20, 1292; (c) Y.-C. Chen, C.-L. Chen, J.-T. Chen and S.-T. Liu, Organometallics, 2001, 20, 1285; $(d)$ K. R. Reddy, K. Surekha, G.-H. Lee, S.-M. Peng and S.-T. Liu, Organometallics, 2000, 19, 2637.

15 (a) M. K. Cooper, J. M. Downes and P. A. Duckworth, Inorg Synth., 1989, 25, 129; (b) R. E. Rülke, J. M. Ernsting, A. L. Spek, C. J. Elsevier, P. W. N. M. van Leeuwen and K. Vrieze, Inorg. Chem., 1993, 32, 5769.

16 S. Antonaroli and B. Crociani, J. Organomet. Chem., 1998, 560, 137. 17 H. A. Ankersmit, B. H. Løken, H. Kooijman, A. L. Spek, K. Vrieze and G. van Koten, Inorg. Chim. Acta, 1996, 252, 141.

18 P. H. P. Brinkmann and G. A. Luinstra, J. Organomet. Chem., 1999, 572, 193.

19 P. Bhattacharyya, J. Parr and A. M. Z. Slawin, J. Chem. Soc., Dalton Trans., 1998, 3609.
20 L. Crociani, G. Bandoli, A. Dolmella, M. Basato and B. Corain, Eur. J. Inorg. Chem., 1998, 1811.

21 R. E. Rülke, J. G. P. Delis, A. M. Groot, C. J. Elsevier, P. W. N. M. van Leeuwen, K. Vrieze, K. Goubitz and H. Schenk, J. Organomet. Chem., 1996, 508, 109.

22 J.-T. Chen, Y.-S. Yeh, C.-S. Yang, F.-Y. Tsai, G.-L. Huang, B.-C. Shu, T.-M. Huang, Y.-S. Chen, G.-H. Lee, M.-C. Cheng, C. C. Wang and Y. Wang, Organometallics, 1994, 13, 4804.

23 P. Braunstein, M. D. Fryzuk, M. Le Dall, F. Naud, S. J. Rettig and F. Speiser, J. Chem Soc., Dalton Trans., 2000, 1067.

24 (a) P. W. N. M. van Leeuwen, P. C. J. Kamer, J. N. H. Reek and P. Dierkes, Chem. Rev., 2000, 100, 2741; (b) M. C. Done, T. Rüther, K. J. Cavell, M. Kilner, E. J. Peacock, N. Braussaud, B. W. Skelton and A. White, J. Organomet. Chem., 2000, 607, 78 . 